\title{
Recreational use Value of a Firefly Watching Ecotourism and Wildlife Park in Palawan, Philippines using the Travel Cost Method
}

\author{
Jessa Marie Salvador-Caabay \\ Faculty, College of Sciences, Palawan State University \\ Puerto Princesa City, Philippines
}

\begin{abstract}
Ecotourism has been known to be globally popular which promotes natural resources that will function for recreational activities but following the methods for sustainable use and implementation. For proper management plans, various ecotourism sites are evaluated for they recreation use values. In this study, the Travel Cost Method (TCM) was applied in order to calculate the economic value of Iwahig Firefly Watching Ecotourism and Wildlife Park in Palawan, Philippines. The individual travel cost method was utilized in this study which was found to be a cost-effective and convenient method. It was found out that age, income and travel costs are some of the factors that have a significant effect on the number of annual visits of individuals in the site. The travel costs and age both have indirect relationship with the number of visits to the site, while the annual income have a direct relationship on the number of visits. This may be useful in terms of management plan and conservation.
\end{abstract}

Keywords - Total Economic Valuation, Ecotourism, Individual Travel Cost Method

\section{INTRODUCTION}

Ecotourism is defined as the responsible travel to natural areas that conserves the environment, sustains the well-being of the local people, and involves interpretation and education (Randall, 1994). It is about uniting conservation, communities, and sustainable travel. Because of the growing popularity and demand of environmentally related and adventure travel, various types of trips are now being classified as ecotourism. Opportunities for ecotourism exist in many different locations worldwide and its activities can vary as widely.

In order to sustain ecotourism, several strategies and methods are being implemented. One of these includes the valuing of certain ecosystem or ecosystem services. Economic valuation is a process that estimates the value of several resources that have no direct use values. Through this method, the value of biodiversity and ecosystem can be communicated through a social and economic view (Gómez-Baggethun \& Ruiz-Pérez, 2011). One of the ways to employ economic valuation is by using the travel cost method (TCM), this method estimates the value of a recreational site or changes in the environmental quality making use of the amount of money or resources and time that people have spent or willing to spend travelling going to that site (Tourkolias, et al., 2015). TCM tries to find out the willingness to pay of individuals for recreational services and activities. This method is considered as advantageous since it relies on observed behaviour that can be that can be tested for accuracy in data (Hawkins, 2003).

Because of the recent recognition given to the Puerto Princesa Underground River last 2011, swarms of tourists have since flocked the city. And because of this popularity, the Iwahig Firefly Watching Ecotourism and Wildlife Park has also been included to most travel itineraries.

Increased tourism to sensitive natural areas like the Iwahig Firefly Watching Ecotoursm and Wildlife Park, without appropriate planning and management can threaten the integrity of ecosystems and local cultures. The increase of visitors to ecologically sensitive areas can lead to significant environmental degradation (Emiriya, et al. 2013). Regardless of these criticisms though, ecotourism and tourism in general are increasing in popularity all over the globe and tourism plays a large role in many worldwide economies (Buckley, 1994), in line with this, an estimation of the recreational use value of Iwahig Firefly Watching Ecotourism using the individual travel cost method was deemed important to be done. 
DOI: $\underline{10.51386 / 25815946 / \mathrm{ijsms}-\mathrm{v} 4 \mathrm{i} 3 \mathrm{p} 111}$

Volume: 4 Issue: 3

May to June 2021

www.ijsmsjournal.org

The results of the study will benefit the park management in terms of analyzing their economic value, which would determine their business strategies and positioning and to justify the value of the ecosystem in the area, in terms of its social benefit.

\section{MATERIALS AND METHOD}

This study utilized a quantitative research design by using the economic valuation technique. Specifically, this study made use of the travel cost method.

\section{A. Research Locale}

This study focused on the valuation of Iwahig Firefly Watching Ecotourism and Wildlife Park which is one of the Community-Based Sustainable Tourism (CBST) Project that was implemented by three selected Barangays, namely: Tagabinet, Iwahig, San Carlos and Maoyon. This program was established by the City of Puerto Princesa that aims to involve local community in the operation and management of the community tourism project as a means of expanding income and livelihood of the residents (City Ordinance No. 546, March $3,2013)$. It also aims to promote conservation, while having a low visitor impact and provide for beneficially active socio-economic involvement of local peoples. The CBSTs encourage tourists to visit their community and experience uniqueness of the site, food, customs, lifestyle and set of activities and practices.

Iwahig Firefly Watching Exotourism and Wildlife Park is located along the mangrove river banks of Iwahig river at Iwahig Prison and Penal Farm, approximately 25 kilometers from the City proper. The total mangrove area of Iwahig River is 350 hectares. It is an initiative of the Iwahig Community Ecotourism Association (ICETA), SEC Reg. No. CN200818188. On October 10, 2008, "Firefly Watching Activity" was introduced and proclaimed as another ecotourism attraction in the city, in partnership with the Iwahig Community Eco-Tourism Association (ICETA), ABS-CBN Bantay Kalikasan, Legend Hotel Palawan and the Puerto Princesa City Tourism Office. The said project has been a success that it won the coveted Pacific-Asia Tourism Association (PATA) Gold Award 2010 for Ecotourism.

\section{B. Valuation Method}

This study made use of Individual Travel Cost Method (TCM) in order to calculate the recreational use value of Iwahig Firefly Watching Ecotourism and Wildlife Park. The travel cost method of economic valuation is a revealed preference method since it evaluates the actual behavior of visitors in terms of the cost of the trip that the individual tourist incurred during the whole trip. The cost of the travel of each visitor is unique to them which was calculated by the summation of the total cost. The aggregate of the observed travel cost associated with the number of individuals accessing the Iwahig Firefly Watching was then evaluated, thus providing a value for the site.

\section{Data Gathering Procedure}

The Travel Cost Method requires information about the visitors to a recreational site. This information was collected by the researchers conducting on-site survey of visitors to the Iwahig Firefly Watching Ecotourism and Wildlife Park. The survey questionnaire, prepared in English, asked about the origin of the visitors, personal profile, travel and miscellaneous expenses and other data required for the travel cost analysis. A sample size of 150 respondents was selected. Random sampling of the visitors was done to capture variations in the origin of visitors.

\section{Statistical Treatment}

According to Das (2013), this ITCM Model can be defined by a 'trip-generation function' (tgf) such as;

$\mathrm{V}=\mathrm{f}(\mathrm{C}, \mathrm{X})$

where,

$\mathrm{V}=$ number of annual visit to the site

$\mathrm{C}=$ visit costs

$\mathrm{X}=$ other socioeconomic variables which significantly explain $\mathrm{V}$.

This formula was adapted in order to evaluate the recreational value of Iwahig Firefly Watching Ecotourism and Wildlife Park. Data gathered through questionnaires were entered into a spreadsheet to evaluate 
travel costs for each visitor. Descriptive statistics and regression analysis were utilized in order to evaluate the data. The mean of the travel costs of all the respondents were computed and regression analysis were used to compute for the relationship between the travel cost, age, and annual income to the number of annual visits of the tourists. This study focused on the valuation of Iwahig Firefly watching which is one of the CommunityBased Sustainable Tourism (CBST) Project that was implemented by three selected Barangays, namely: Tagabinet, Iwahig, San Carlos and Maoyon. This program was established by the City of Puerto Princesa that aims to involve local community in the operation and management of the community tourism project as a means of expanding income.

\section{III.RESULTS AND DISCUSSION}

In the Individual Travel Cost Method, the number of visits made by tourist in a year is used as a dependent variable while the total travel costs incurred by the individual, age and annual income of the visitor were used as the independent variables.

Based on the results, it was found out that during the time of the survey, all of the visitors were local tourists coming from different areas within the Philippines. Majority of the visitors were also found to be from the National Capital Region (NCR). The travel cost of local visitors varied between P700.00 and 18,700.00 per visit, with an average of P 8,229.14. According to ICETA, 23,400 visitors approximately visited the Iwahig Firefly Watching Ecotourism and Wildlife Park, therefore the annual economic value of the said area in terms of the average travel costs of individuals visiting it is approximately Php 192,561,876.00

\section{A. Travel Costs}

In Travel Cost Method studies, the costs of travel are the most important independent variable that determines the value of consumer surplus. In this study, all the expenses incurred from land and air fares, accommodation, the cost of the tour as well as the entrance fee were considered as travel cost. The age and annual income of the visitors were also regarded independent variables in the study.

\section{B. Model Specifications}

In this study, the Individual Travel Cost Method (ITCM) was used to evaluate the recreational use value by relating demand for the said ecotourism activity (measured as annual site visits) to its price (measured as the travel cost of individual visiting the site).

The demand function of the valuation of Iwahig Firefly Watching was formed as follows:

$\mathrm{Vak}=\mathrm{f}(\mathrm{TCak}, \mathrm{Aa}, \mathrm{Ia})$

Vak : Number of annual visits of individual.

TCak : Travel costs of individual.

Aa : Age.

Ia : Annual Income.

Based on the results, the function was found to be significant at the 5\% level having a regression of 0.093 . Results in the model variables are parallel to the theoretical expectations in TCM (Travel Cost Method) applications (Spacek and Antouskova, 2013).

The different factors and variables in the study such as the age, annual income, and travel cost of the visitors were evaluated using regression analysis depicted in table 1 below.

Table 1 Regression Analysis of the different factors

\begin{tabular}{|l|l|l|l|l|l|}
\hline Variables & coefficients & std. error & $\boldsymbol{t}(\boldsymbol{d} \mathbf{f = 3 1})$ & $\boldsymbol{p}$-value & std. coeff. \\
\hline Intercept & 0.8604 & 0.5243 & 1.641 & .1109 & 0.000 \\
\hline Age & -0.0017 & 0.0140 & -0.122 & .0090 & -0.022 \\
\hline Annual Income & 0.00000051 & 0.00000085 & 0.593 & .0457 & 0.108 \\
\hline Travel Cost & -0.00005079 & 0.00003293 & 1.542 & .01332 & 0.269 \\
\hline
\end{tabular}


DOI: $\underline{10.51386 / 25815946 / \mathrm{ijsms}-\mathrm{v} 4 \mathrm{i} 3 \mathrm{p} 111}$

The negative (-) value on the travel cost variable (Table 1) shows that there is an indirect relation between the travel costs and the annual number of visits. This implies that as the travel costs for a specific destination increases, the number of annual visits might decrease. The age as an independent variable also shows an indirect relationship to the annual visit of tourists to Iwahig firefly watching, showing that younger visitors are more likely to have more than one annual visit on the said site. Annual income on the other hand showed a positive coefficient with the number of annual visits indicating that as annual income increases, number of annual visits increases also.

Based on the regression analysis, it was also found out that age and the numbers of annual visits are indirectly proportional. Iwahig Firefly watching is a destination for both the adventurous and nature-lover tourists because of its scenery and activities involving paddling on brackish water while watching the glow of fireflies. Most types of tourists attracted to the area are the young and those bent on exploring Palawan. Age plays an important role in the types of experiences that appeal to the person. Younger people tend to select more adventurous activities and have high tolerance for varied and new experiences compared to the elderly.

The age of visitors was considered according to age bracket as follows: 10-20, 21-30, 31-40, 41-50 and 51- 60 years old. Majority of the visitors where within the age bracket of 21 to 31 at around 54\% followed by visitors ageing 31 to $40(26 \%)$, then tourists within 41 to 50 of age (14\%), and lastly by visitors from the age bracket 10 to 20 and 51 to 60 both making up $6 \%$ of the total number of respondents.

The annual income of the visitors was considered based on the following distributions: below 100,000, 101,000 to $200,000,201,000$ to $300,000,301,000$ to $400,000401,000$ to 500,000 and 501,000 to 600,000 (all in Philippine Peso). Based on the findings of the study, it was found out that majority of the tourists visiting the area is within the annual income bracket of 201,000 Pesos to 300,000 Pesos. This shows that the access to firefly watching is not that costly for even the "average" could afford to enjoy such tourist destination.

\section{Consumer Surplus}

The value of consumer surplus was also calculated in order to compute for the annual social benefit of the Iwahig Firefly Watching

In this study, the following formula was used to estimate the consumer surplus:

$\mathrm{CS}=\mathrm{q} /-\beta_{\mathrm{SL}}$ where

CS: Consumer surplus of individual visitor

$\mathrm{q}$ : Average of the total annual number of visits,

$\beta$ : Curve of the demand function (cost coefficient from Table 3. Regression Output).

When the values were put into the formula, the individual consumer surplus was estimated to be:

$\mathrm{CS}=1 /-(-0.00005079)=$ Php 19,688.92

Based on data obtained from ICETA, an average of 23,400 persons visited Iwahig Firefly Watching Ecotourism and wildlife park annually., this value was multiplied by the individual consumer surplus to estimate total consumer surplus (TCS):

TCS $=$ CS x23,400

$=$ Php 19,688.92 x 23,400 = Php 460,720,728.00

The value of the consumer surplus represents the annual recreational use value of the said destination. In other words, the Park provides a social benefit of some Php Php 460,720,728.00 each year.

\section{IV.CONCLUSIONS}

Based on the findings of this study, it was found out that age, income and travel costs are some of the factors that have a significant effect on the number of annual visits of individuals in the Iwahig Firefly Watching Ecotourism and Wildlife Park. It was observed that majority of the visitors are within the age bracket of 21 to 30 years old with an annual income of 201,000 to 300,000 Philippine Peso. The travel cost of local visitors varied between P700.00 and 18,700.00 per visit, with an average of P 8,229.14. The annual economic value of the said area in terms of the average travel costs of individuals visiting it is approximately Php 192,561,876.00

Based on the regression analysis, it was evaluated that the travel costs and age both have indirect relationship with the number of visits to the site, while the annual income have a direct relationship on the number of visits. At the time of the study, it was also noted that all of the visitors are local tourists from all over the Philippines, 
majority of which are from the National Capital Region. Furthermore, using the consumer surplus, it was calculated that the Park provides a social benefit of some Php 460,720,728.00 each year.

Moreover, this study shows the use of travel cost method in evaluating the recreational use value of a tourism site. This may be useful in terms of management plan and conservation.

\section{REFERENCES}

[1] Buckley, R. (1994). A framework for ecotourism. Annals of tourism research,21(3), 661-665.

[2] Cater, E., \& Lowman, G. (1994). Ecotourism: a sustainable option?. John Wiley \& Sons.

[3] Das, Sukanya.(2013). Travel Cost Method For Environmental Valuation. Center of Excellence in Environmental Economics.

[4] Emiriya, M. and Robson, M. (2013). An application of the individual Travel Cost Method to Nyanga National Park, Zimbabwe. Researchjournali's Journal of Economics: 1(1). pp. 1-16.

[5] Gómez-Baggethun, E., \& Ruiz-Pérez, M. (2011). Economic valuation and the commodification of ecosystem services. Progress in Physical Geography, 35(5), 613-628.

[6] Hawkins, K. (2003). Economic valuation of ecosystem services. University of Minnesota, 23.

[7] Kiss, A. (2004). Is community-based ecotourism a good use of biodiversity conservation funds?. Trends in Ecology \& Evolution, $19(5), 232-237$.

[8] Randall, A. (1994). A difficulty with the travel cost method. Land economics, 88-96.

[9] Spacek, Jan and Antouskova, Michaela. (2013). Individual Single-Site Travel Cost Model For Czech Paradise Geopark.Acta Universitatis Agriculturae Et Silviculturae Mendelianae Brunensis, 61(1), pp. 2851- 2858.

[10] Tobias, D., \& Mendelsohn, R. (1991). Valuing ecotourism in a tropical rain-forest reserve. Ambio, 91-93. (Size 8) S. M. Metev and V. P. Veiko, Laser Assisted Microtechnology, 2nd ed., R. M. Osgood, Jr., Ed. Berlin, Germany: Springer-Verlag, 1998.

[11] Tourkolias, C., Skiada, T., Mirasgedis, S., \& Diakoulaki, D. (2015). Application of the travel cost method for the valuation of the Poseidon temple in Sounio, Greece. Journal of Cultural Heritage, 16(4), 567-574. 